\title{
An Exploration of Ethnic Dynamics in Nepal
}

\author{
Himal Giri (Ph. D. Scholar)*
}

\begin{abstract}
This article explores manifold dynamics of demographic presence in Nepal. The polities at large are distinct in terms of culture, class and caste. The study focuses on ethnic differences in the context of the recent political development of Nepal. Demographic changes have profound effects on the society, economy, and people of a political institution. Nepal is a multiethnic country with a history of ethnic discrimination over the centuries because of racial differences imbibed in political and social affairs of the Nepalese. Demographic changes in Nepal have occurred under unique circumstances within a both a historical context and a contemporary and comparative perspective against other countries have encountered. The article encompasses the factors such as cultural harmony, integrity, and equity to analyze cultural differences and racial realities in the scenario of the postmodern era. The paper unfolds the pages of underrepresentation of the marginalized communities and overrepresentation of Indo-Aryan groups and Newar in the polity.
\end{abstract}

Key words: Ethnicity, race, development, caste, indigenous, difference \& language.

\section{Introduction}

The paper shows the demographic dynamics in terms of ethnicities. Diversity in Nepal is ubiquitous. Ethnic groups are a product of both the colonial and state-building eras of Nepal. The groups use diverse languages, celebrate different festivals, and practice distinct customs and rituals. They are categorized by common culture and endogamy. Endogamy carves out ethnic groups in Nepal. Khas comprising Bahun, Chhetri, Kami, Damai and others. Dalits are the largest ethno-linguistic group in Nepal. Nepal's diverse linguistic heritage evolved from three major language groups: Indo-Aryan, Tibeto-Burman languages, and various indigenous language isolates. According to the 2001 national census, ninety-two different living languages are spoken in Nepal. Based upon the 2011 census, the major languages spoken in Nepal are Nepali, Maithili and Bhojpuri. Since Nepal's unification, various indigenous languages have come under threat of extinction

*Mr. Giri is a Faculty Associate at the Department of English, Patan Multiple Campus, TU, Lalitpur, Nepal. Email: himalgiri2017@gmail.com 
as the government of Nepal has marginalized their use through strict policies designed to promote Nepali as the official language. Indigenous languages have gone extinct. After the restoration of democracy in 1990, the government has worked to improve the marginalization of these languages.

\section{Statement of the Problem}

The racial and ethnic groups in the country have been sidelined in almost all respects of human development. In fact, the changes and desires for transformations of political system pervade in all ethnic groups. Ethinic diversification has prominent impact on social, political and economic aspects of the people. So, it is expected that the differences will be addressed impartially from the perspective of equity. On the other hand, the sociopolitical scenario has been discriminatory from different perspectives. The marginalized groups have been deprived of resources and humiliation in the society. Therefore, the socio-political environment deems to get comfortable for a more peaceful, happier, and more prosperous life in the country.

\section{Objectives}

The main objective of the study is to configure the racial and ethnical confrontation at both political and cultural levels in Nepal. Specific objectives of this study are to analyze the historical development in terms of ethnicity and race and to explore the challenges that marginalized communities have been facing over the years.

\section{Justification}

The significance of the study lies in the analysis of the current ethnic and racial conflicts in Nepal. Since the restoration of democracy, the country has been undergoing challenges based on the cultural and ethnic differences. The diversity in the social composition in the country is prominent. Conversely, it has not become a fertile ground for the political and social actors to take advantages. The study demonstrates the possibilities of managing the cultural and social conflicts. This article gives insight to the responsible position holders to solve the ethnic problems of the country. The next significant aspect is that the ethnic people grasp it's impact, insight over racial and ethnic confrontation, ethnic historical development, the challenges of marginalized community, are inevitable to the concerned people.

\section{Methodology}

This qualitative study has adopted the analytical and exploratory approaches to study secondary data on ethnicity and racial issues in Nepal. 


\section{Analysis and Interpretation of the Results}

The research paper investigates into ethnic dynamics of Nepal to study the demographic and cultural status of different groups that compose Nepalese culture. Race refers to the contrasted presence of color and countenance. It relies upon the community, geography, climate, gene, origin and so on. People though are considered to have been from some ancestors originally, are different in looks and thoughts now which invites many curiosities and hypotheses. Why humanity differs even if its genesis is the same that triggers consciousness of sensible beings despite their distinct locations and bringing-ups is the prime point of discussion. Race is not synonymous to ethnicity. Mostly people take these terms just as alternatives, which is mischievous and wrongful. Race and ethnicity are greatly different from each other. These words are with big concepts. Transmission of social terms requires expertise in scholars and advocates.

The restructuring of the country by addressing the grievances of the oppressed is the essentials and demand of the time. Groups excluded from state power were designated for proportional inclusion, mostly through quotas ('reservations'), in education, public employment, and political representation. The main beneficiaries were women, Dalit, ethnic groups-the latter now called indigenous (janajati adivasi)-the residual category of 'other marginalized groups', and, especially in an electoral context, the people in the lowland region bordering on India who define themselves as Madhesis. When the Constituent Assembly convened, members spoke the accepted political language of 'social inclusion' regardless of class, caste and ethnicity (Tamang, 2012).

These different sections of the society have always survived the deprivation from different facilities provided by the government over the centuries. The situation is still not so good. The actual plight of the ethnic groups of Nepal can be measured in terms of the human development index. The resources and quality education count significant when talking about degradation and marginalization of the downtrodden people in Nepal. Tamang argues:

Economic growth, urbanization, migration, improved education, and health across the board, and the reduced importance of agriculture in a more diversified economy were eroding the social foundations and legitimacy that for so long had enabled a small social segment to control the levers of state power. The new forces were expressed most dramatically in the massive 'people's movement' in April 2006, when hundreds of thousands of demonstrators from all social strata and from all over the country clogged the streets of Kathmandu to call for peace and democracy. 
The dependency of the ethnicities on the conventional occupations previously has changed because of economic development, migration, and health awareness. People seek for quality education and opportunities to change their life styles. Consequently, huge migration from the village to the cities is observable. Dynamic populace has also sought for political changes in the nation for independence, openness, and transparency in the governance. The inclination for sharable rule has heightened over the years. The political reorganization of the country respects the spirit for changes and development among the ethnic groups. Tamang asserts:

No decision had been made regarding the explicit criteria for boundary demarcation, or for that matter on the principles of devolution of power from the center to the sub-units. As the Assembly's term was about to end, the caucus wanted a vote on the floor where they claimed they had the numbers to pass the 11-state proposal. To preempt a vote, the party leaders took the issue off the floor for informal discussions, effectively stalling the process until the deadline for adjournment had passed. The Constituent Assembly adjourned, leaving the grand project of restructuring the state hanging.

In spite of a spectacular demonstration of the marginalized sections of the society in the constituent assembly of 2008, they could not ensure their rights and spirits for changes in the constitution, as the drafting of the constitution was not concluded. The disaster led to political anarchy as well. The prominent political parties that affected the policies and political decisions of the country exemplified the elites. Ethnic activists judged in terms of caste and ethnicity rather than party noted that the number of janajati representatives elected was almost the same as in 2008, and that the representation from the Terai had increased.

The majority of the population falls within four large linguistic family groups, IndoAryan, Tibeto-Burman, Austro-Asiatic, and Dravidian. These groups are further subdivided into numerous sub-groups, castes, and tribes. However, Indo-Aryans form the largest ethno-linguistic group not only in Nepal but also in North India, Bangladesh, Pakistan, Sri Lanka, and the Maldives. In Nepal, the size of various ethnic/caste groups in the total population was hardly known before 1990 despite Nepal being a multiethnic, multilingual, and multicultural country. The eleventh census of 2011, for the first time, identified more than 125 ethnic/caste groups and more than 123 languages in multiethnic Nepal (Suhrke, 2014). The societal structure and cultural composition of these countries is alike because of linguistic variations.

Issues of ethnic and regional equity seem to dominate the agenda of the new republican government and continue to be divisive. Even after the end of a 10-year-old Maoist 
conflict, the upper caste dominates every field in Nepal. Specifically, Brahmin and Chhetri (Indo-Aryan) have advantages. Although Newars are low in numbers, their urban living habitat gives them a competitive advantage. On a similar note, Newars are at the top of the Human Development Index. From a gender perspective, Newari women are the most literate and lead in every sector. Brahmin and Chhetri women have experienced less social and economic mobility compared to Newari women. Specifically, Brahmin women experience less equality due to their predominately-rural living conditions and patriarchal behavior that deprives them of access to certain educational and healthcare benefits. Nepal has been experiencing social exclusion of people in terms of both race and ethnicity over the years.

The favoritism and dispossession of people regarding race and ethnicity remain but in new forms and structures. Excluded groups who are the victim endure from multiple disadvantages that may come together when they have manifold sufferings, unequal rights, denied rights, discriminated, and feel marginalized from the mainstream society. Social excluded people can be an easy victim of discriminations and conventional behavior in education (Suhkre, 2014). The deprived and excluded segments of society feel discouraged to interact with the people around in open manners. Due to low confidence, they cannot play proactive roles in nation building acts.

The gap between the excluded and the included in the ethnic and racial line pervades the country. The excluded have a free say in hardly any areas. The underrepresentation of the excluded namely Dalits, Muslims, Janjatis, Madhesis and the overrepresentation of the Brahmins, Chhetris and of Newars in the countryreflectsthe disparity. Theoverrepresentation of some groups such as Brahmin-Chhetri and Newar and underrepresentation of others such as Dalits, ethnic groups, Madhesis and religious minorities in education, the state and polity is pervasive (Suhkre, 2014). State restructuring becomes a burning contentious issue when a country is going federal based on desegregation.

The Federal Democratic Republic of Nepal is one of the countries forming the South Asian region. The landlocked country is surrounded by China \& India. Nepal has a total land area of 147,181 square kilometers, the 93rd largest country in the world. Nepal is a multi-ethnic country with Nepalise being the official language. The country has a population of over 28 million people with an average family size of 4.9 . Nepalese equate their nationality to citizenship rather than ethnicity. However, state restructuring because of ethnic federation remains highly undecided and controversial and it continues to disease state restructuring debate and constitution drafting succession. The best-elected federalism should be based on geographic, regional, and economic factors with an acceptance of regional, cultural, 
and linguistic differences. For this, the reconsideration of the electoral constituencies is necessary so that to stand for the populations in them that would spoil the concerns of the ethnic groups and their genuine population is represented correctly based on collective rights rather than ethnic identity. People of all religions, regions and ethnic hierarchies, including high caste Hindus in diverse regions, have been struggling to carry on under unhappy specification. Prakash Upadhyay (2013) states:

The particular policy issue examined here is how to overcome the persistent legacy of interconnected caste, ethnic and gender-based exclusions. While the major impetus for this kind of social change comes from individuals and groups who have themselves been excluded, there is also an important group in the civil service who are behind this change. Even though as 'high caste' males, they are part of the current configuration of power, they are supporting policy change at least in part because they see themselves as champions of 'economic reform'. First and foremost, they see these exclusions as a block to poverty reduction and economic growth-and also as one of the reasons the insurgency has gained such momentum across the countryside. For them 'economic reform' is more than the enactment of a particular set of economic policies. It stands in opposition to the patronage-based system of governance that has marked Nepal's past and connotes the modern rulebased state they seek to create.

The political analysis reflects some achievements and nominal reformations in the contemporary Nepal. The real advantages of democratization are still limited to few large portion of the people. Even greater part of the society is away from the taste of democracy. The powerlessness of the ethnic communities is a terrible problem in terms of development. The requirement of mutual respects for the cultural differences is a basics of multiculturalism.

The social exclusion in social arenas has been because of the rigid demarcation of castes and ethnicities across the nation. The realization of this evil has eased the path of democratization after the restoration of democracy in 1990. Upadhayay argues that empowerment is seen as occurring at the individual and group level and, to an important extent, has to do with changes in the internal self-perceptions of those who have been in some way negatively defined and marginalized by the dominant society. It also has to do with increasing their access to assets, capabilities and voice, and helping them to realize the power they gain from collective action. All of this builds their sense of agency or their capacity to act on their own behalf. Often empowerment approaches work at the grassroots, "from below", helping diverse groups of poor and socially excluded citizens 
to organize themselves to improve their livelihoods and to demand broader institutional change. These approaches are most effective when they can be scaled up to stimulate the formation of coalitions for change between excluded groups and other better-off citizens who also want a more equitable society - or share other interests with the excluded. Empowerment of the marginalized community can be probable provided the ruling section grows liberal and tolerant. Inclusion of the excluded communities in the process of nation is indispensable. The policy makers need to accommodate the grievances of the marginalized groups for political strength and economic development of all ethnicities and classes. Lynn Bennett states:

In the ethnic-based state, ethnic groups are fundamental building blocks of the political system and many rights of citizenship can only be exercised through membership of an ethnic group. Citizenship rights are differentiated. Representation and participation are based on ethnic distinctions. Therefore, group rights are frequently more important than individual rights. There is often explicit recognition in the public sphere of cultural differences between communities, blurring the distinction between the public and private.

The excluded communities may lag behind in the process of development. The latent of ethnic mobilization depends on proper factors: whether the community feels discriminated against, excluded, subjugated, its culture threatened, etc. These background factors change over time, and with it come shifts in identity. Identity politics does not recognize the fluidity of identity, and constitutional and political arrangements based on passing identities tend to form identity.

\section{Conclusion}

The presence of diverse cultural groups prominently Indo-Aryan, Indigenous, and Madheshi displays the demographic and ethnic strength in Nepal. The political changes over the decades have become the foundations for the economic and social development. The requirement of mutual respect and acceptance of differences is one of the most necessary things that every stakeholder has to consider. The substantial unification for the progressive development of Nepal lies in the consolidation of distinct cultural properties.

A community is a common house of all the diversified people. Therefore, the cultural harmony, integrity, and equity to cultural differences should be evaluated and maintained for the communal development. The racial superiority and inferiority are traditionally the obstacles to unite a person together that enhances the discrimination in the society. Therefore, ethnic differences should be taken as an asset of the country to create respective 
environment for them to settle in the society. The concerned stakeholders should implant vision, mission, and strategy for the welfare of ethnic dynamism in the country. The presence of diverse ethnicities in the Nepalese society indicates that the mutual respect for each ethnic group regardless of their racial and social differences must retain for the holistic development of the country.

\section{References}

Bennett, L. (2005). Gender, caste and ethnic exclusion in Nepal: Following the policy process from analysis to action." New Frontiers of Social Policy. Conference paper, Arshu Conference.

Central Bureau of Statistics (CBS). (2003). Population monographs of Nepal 2001. Kathmandu: National Planning Commission Secretariat, Central Bureau of Statistics, Nepal.

Central Bureau of Statistics (CBS). (2014). Population monographs of Nepal, 2011, Vol. II. Kathmandu: National Planning Commission Secretariat, Central Bureau of Statistics, Nepal.

Ghai, Y. (n.d.). Ethnicity, identity, participation and social justice: A constitution for new Nepal. https://pdfs.semanticscholar.org/5912/1986c6d0d8442db7e1f5314d52acb8d6b27a.pdf

Government of Nepal (GoN). (2017). Demographic changes in Nepal: Trends and policy implications. Kathmandu: National Planning Commission Secretariat, Government of Nepal, Nepal.

Suhrke, A. (2014). Restructuring the state: Federalist dynamics in Nepal. Chr. Michelson Institute, Bergen, Norway.

Upadhyay, P. (2013). Ethnicity, stereotypes and ethnic movements in Nepal. Crossing the Border: International Journal of Interdisciplinary Studies. https://doi.org/10.3126/ctbijis. v1i1.10470. 